\title{
Analysis of mutations to gyrA in quinolone- resistant clinical isolates of Enterobacter cloacae
}

\author{
CHRISTINE DEKITSCH, ROBERT SCHEIN, EFFI MARKOPULOS, BEATRIX KUEN*, \\ WOLFGANG GRANINGER and APOSTOLOS GEORGOPOULOS \\ Department of Infectious Diseases and Chemotherapy, University Clinic of Internal Medicine I, Vienna and \\ *Institut für Mikrobiologie und Genetik, Biozentrum der Universität Wien, Vienna, Austria
}

\begin{abstract}
The gyrA subgenes of a quinolone-resistant Enterobacter cloacae clinical isolate (ofloxacin MIC, $16 \mathrm{mg} / \mathrm{L}$ ) and of a control, E. cloacae NCTC 10005 (ofloxacin MIC, $0.03 \mathrm{mg} / \mathrm{L}$ ), were amplified by polymerase chain reaction (PCR) and sequenced. The resistant isolate had mutations at the codons for amino acids 83,89 and 90 . The first of these mutations led to replacement of serine-83 by tyrosine, whereas the other mutations were silent. Digestion of PCR-amplified DNA fragments with the restriction enzyme Hinf I detected mutations at the same site in $g y r A$ in six further quinolone resistant $E$. cloacae isolates.
\end{abstract}

\section{Introduction}

An increase in the incidence of serious diseases caused by Enterobacter cloacae has been observed recently $[1,2]$. Nosocomial infections caused by $E$. cloacae are often treated with fluoroquinolones, because of resistance to many other agents [3]. Quinolones act primarily by inhibiting DNA gyrase (topoisomerase II) [4-6], which is essential for bacterial growth [7]. DNA gyrase transiently breaks the DNA strands and introduces negative superhelical turns in an ATPdependent process [8]. Apart from being involved in DNA replication, this enzyme regulates the initiation of transcription of several genes. The enzyme is a tetramer with two A and two B subunits encoded by the genes $g y r A$ and $g y r B$, respectively.

Mechanisms of resistance to fluoroquinolones have been studied in several gram-negative organisms including Escherichia coli, Pseudomonas aeruginosa, Acinetobacter baumannii and Salmonella typhimurium [9-12] and were found to be chromosomally determined. In most cases, high-level fluoroquinolone resistance in these organisms maps to mutations in gyrA $[13,14]$. Such mutations result in a simultaneous increase in resistance towards all quinolones. Most mutations in Esch. coli lie in the $5^{\prime}$ end of gyrA, between nucleotides 199 (corresponding to Ala-67 in the protein product) and 318 (Gln-106). This region

Received 9 Dec. 1997; revised version received 27 April 1998; accepted 29 April 1998.

Corresponding author: Professor A. Georgopoulos. contains the regulatory centre, tyrosine $122[15,16]$ and has been termed the 'quinolone-resistance-determining region' (QRDR). The present study determined the nucleotide sequence of the QRDRs of quinolonesensitive and -resistant strains of E. cloacae.

\section{Materials and methods}

\section{Bacterial strains}

E. cloacae strains were collected from different clinical specimens at the University Hospital of Vienna and were identified by the API $20 \mathrm{E}$ system (bioMerieux, Marcy l'Etoile, France). E. cloacae NCTC 10005 and Esch. coli ATCC 25922 were used as reference strains for antimicrobial susceptibility testing. Esch. coli S17-1, carrying the plasmid pLA2917, and Esch. coli S17-1 carrying the plasmid pNJR3-2, were used as the donor strains for conjugation [7].

\section{Antimicrobial susceptibility testing}

MICs were determined by a microdilution method in Mueller Hinton Broth (Merck, Darmstadt, Germany) with final inocula of $10^{5} \mathrm{cfu}$. The quinolones used were ciprofloxacin (Bayer, Vienna, Austria), ofloxacin (Hoechst, Vienna, Austria) and nalidixic acid (Sterling Winthrop, Dijon, France).

\section{Conjugation}

Plasmid pLA2917 (tet $\left.{ }^{+}\right)$, carrying a tetracycline resistance gene and pNJR3-2 $\left(\right.$ tet $^{+}$, gyr $\mathrm{A}^{+}$), carrying 
the tetracycline resistance gene in addition to the cloned wild-type gyrA gene of Esch. coli were used. Each of these plasmids was transferred into 10 randomly chosen isolates, with ofloxacin MICs $\geqslant 1 \mathrm{mg} / \mathrm{L}$. To achieve transfer, the isolates were cultured in $10 \mathrm{ml}$ volumes of Mueller Luria Broth [7], whilst the donor strains were cultured overnight in $10-\mathrm{ml}$ amounts of Mueller Luria broth containing tetracycline (WyethLederle, Vienna, Austria) $5 \mathrm{mg} / \mathrm{L}$. Equal volumes ( $1 \mathrm{ml}$ of donor and recipient were then mixed and the mixtures were centrifuged $(13200 \mathrm{~g})$ for $5 \mathrm{~min}$ at $4^{\circ} \mathrm{C}$. The pellets were suspended in $50-\mu 1$ amounts of $0.15 \mathrm{M}$ $\mathrm{NaCl}$, spread on Mueller Luria agar and incubated for $5 \mathrm{~h}$ at $37^{\circ} \mathrm{C}$ to allow mating, then harvested into $3-\mathrm{ml}$ volumes of sterile $0.15 \mathrm{M} \mathrm{NaCl}$. Dilutions containing $c$. $10^{2}$ and $10^{4} \mathrm{cfu} / \mathrm{ml}$ were made in $10-\mathrm{ml}$ volumes of sterile water, and $100-\mu \mathrm{l}$ volumes were spread on MacConkey agar (Oxoid, Basingstoke, Hants) containing tetracycline at $0,20,100$ and $200 \mathrm{mg} / \mathrm{L}$. Presumptive transconjugates recovered on this medium after incubation overnight at $37^{\circ} \mathrm{C}$ were subcultured on MacConkey agar plates containing tetracycline $100 \mathrm{mg} / \mathrm{L}$. They were then confirmed as E. cloacae and MICs were determined as above, but with tetracycline $(5 \mathrm{mg} / \mathrm{L})$ added to the Mueller Hinton broth to conserve the plasmids.

\section{Polymerase chain reaction (PCR)}

Two oligonucleotide primers (Dr Müller, Oligo-Ocom, Vienna Biocenter, Austria), Pri 1 (5'-TACACCGGTCAACATTGAGG-3') and Pri2 (5'-TTAATGATTGCCGCCGTCGG-3') were designed, on the basis of the known gyrA sequences of Esch. coli K-12. Pril was identical in sequence to nucleotide positions 2443 , and Pri2 was complementary to positions $652-671$. These were used to amplify gyrA by PCR [17]. Template DNA was prepared from each strain by heat $\left(37^{\circ} \mathrm{C}\right)$ and cold shock $\left(-196^{\circ} \mathrm{C}\right)$ treatment of single colonies suspended in water, followed by centrifugation. The template DNA was taken from the resulting supernate and amplification was performed in a final volume of $50 \mu \mathrm{l}$ containing $5 \mu \mathrm{l}$ of DNA template (30$50 \mathrm{ng}$ ), $0.8 \mu \mathrm{l}$ of each primer (Pril and Pri2 each at $20 \mu \mathrm{M}$ ), $5 \mu \mathrm{l}$ of deoxynucleoside triphosphates (dATP, dCTP, dGTP and dTTP; $2 \mathrm{mM}$ each; Perkin-Elmer, Branchburg, NJ, USA), and $5 \mu \mathrm{l}$ of Taq buffer containing $1.0-2.0 \mathrm{U}$ of Taq polymerase (PerkinElmer), which was added after the sample had been heated. Thirty amplification cycles were used, with the following temperature profiles: $92^{\circ} \mathrm{C}$ for $35 \mathrm{~s} ; 64^{\circ} \mathrm{C}$ for $1 \mathrm{~min}$ and $74^{\circ} \mathrm{C}$ for $2 \mathrm{~min}$.

\section{Sequence analysis}

PCR fragments were subjected to phenol-chloroform extraction and then precipitated with ethanol [18]. Double-stranded PCR fragments were sequenced by an automated DNA sequencing system, with a fluores- cence sequencer (LI-COR; Lincoln, Nebraska, USA) [19].

\section{Restriction fragment length polymorphism (RFLP) of PCR-amplified DNA}

The 648-bp fragment amplified by PCR was digested with Hinf I [17] (Amersham, Bucks) at $37^{\circ} \mathrm{C}$ for $1 \mathrm{~h}$. The cleavage products were profiled by electrophoresis in gels containing agarose $1.5 \%$ in TAE buffer and ethidium bromide staining [17].

\section{Results \\ Antimicrobial susceptibility}

The susceptibilities of clinical E. cloacae isolates are shown in Table 1. The most resistant isolates were nos. 89 and 132; isolates 5, 15, 19, 32, 67, 68, 105, 110 had diminished susceptibility to fluoroquinolones as compared to isolate 136 and E. cloacae NCTC 10005. All the isolates except no. 136 were resistant to nalidixic acid.

\section{Dominance test}

The susceptibilities of donor strains, E. cloacae isolates and transconjugants are shown in Table 1. All transconjugants with plasmids pLA2917 and pNJR3-2 became resistant to tetracycline. Four isolates (nos. 5, 15,32 and 105) of those acquiring plasmid pNJR3-2 retained diminished susceptibility to ofloxacin, but six (isolate nos. 19, 67, 68, 89, 110 and 132) became more sensitive to this quinolone. Notably, the isolates in which acquisition of pNJR3-2 reduced or eliminated resistance were those that began with the highest levels of resistance to the quinolones. In contrast to its gyr $A$ coding derivative, pLA2917 had no effect on quinolone MICs.

\section{PCR products and point mutations in gyrA}

PCR products consistently had the mobility expected for a 648-bp DNA fragment (Fig. 1). Sequencing of the 338-bp fragment corresponding to the N-terminal region of GyrA from the most quinolone-resistant isolate (no. 89) showed three alterations in comparison with that of the quinolone-susceptible control $E$. cloacae NCTC 10005 (Table 2). Silent mutations were present in the codons determining amino acids 89 (ATC to ATT) and 90 (GTT to GTC); in addition, the codon corresponding to amino acid 83 was altered from TCC in the control to TAC in the resistant isolate, indicating a serine to tyrosine substitution.

\section{PCR-RFLP}

PCR products of QRDR region were $648 \mathrm{bp}$ long and were expected to have two Hinfl recognition sites. Thus, HinfI digestion was predicted to yield three 
Table 1. MICs for ofloxacin, ciprofloxacin and tetracycline for donors, E. cloacae isolates and their transconjugants

\begin{tabular}{|c|c|c|c|c|}
\hline \multirow[b]{2}{*}{ Strains and plasmids } & \multicolumn{4}{|c|}{$\mathrm{MIC} \mathrm{mg} / \mathrm{L}$} \\
\hline & Nalidixic acid & Ciprofloxacin & Ofloxacin & Tetracycline \\
\hline $\begin{array}{l}\text { Esch coli S17-1 (pLA2917) } \\
\text { Esch. coli S17-1 (pNJR3-2) }\end{array}$ & $\begin{array}{l}\cdots \\
\cdots\end{array}$ & $\begin{array}{l}\leqslant 0.01 \\
\leqslant 0.01\end{array}$ & $\begin{array}{l}\leqslant 0.01 \\
\leqslant 0.01\end{array}$ & $\begin{array}{l}128 \\
128\end{array}$ \\
\hline $\begin{array}{l}\text { E. cloacae } \mathrm{NCTC} 10005 \\
\text { E. cloacae } 136\end{array}$ & $\begin{array}{l}2 \\
4\end{array}$ & $\leqslant \begin{array}{r}0.01 \\
0.01\end{array}$ & $\begin{array}{l}0.03 \\
0.06\end{array}$ & - \\
\hline $\begin{array}{l}\text { E. cloacae } 5 \text { (no plasmid) } \\
5 \text { (pLA2917) } \\
5 \text { (pNJR3-2) }\end{array}$ & $\begin{array}{r}32 \\
\cdots \\
\cdots\end{array}$ & $\begin{array}{l}0.12 \\
0.12 \\
0.12\end{array}$ & $\begin{array}{l}1 \\
1 \\
1\end{array}$ & $\begin{array}{r}32 \\
\geqslant 256 \\
\geqslant 256\end{array}$ \\
\hline $\begin{array}{l}\text { E. cloacae } 15 \text { (no plasmid) } \\
15 \text { (pLA2917) } \\
15 \text { (pNJR3-2) }\end{array}$ & $\begin{array}{l}128 \\
\ldots \\
\cdots\end{array}$ & $\begin{array}{l}0.12 \\
0.12 \\
0.12\end{array}$ & $\begin{array}{l}0.5 \\
0.5 \\
0.5\end{array}$ & $\begin{array}{r}32 \\
\geqslant 256 \\
\geqslant 256\end{array}$ \\
\hline $\begin{array}{l}\text { E. cloacae } 19 \text { (no plasmid) } \\
19 \text { (pLA2917) } \\
19 \text { (pNJR3-2) }\end{array}$ & $\begin{array}{l}\geqslant 256 \\
\quad \ldots \\
\ldots\end{array}$ & $\begin{array}{l}0.5 \\
0.5 \\
0.03\end{array}$ & $\begin{array}{l}2 \\
2 \\
0.25\end{array}$ & $\begin{array}{r}8 \\
\geqslant 256 \\
\geqslant 256\end{array}$ \\
\hline $\begin{array}{l}\text { E. cloacae } 32 \text { (no plasmid) } \\
32 \text { (pLA2917) } \\
32 \text { (pNJR3-2) }\end{array}$ & $\begin{array}{l}32 \\
\cdots \\
\cdots\end{array}$ & $\begin{array}{l}0.12 \\
0.12 \\
0.12\end{array}$ & $\begin{array}{l}1 \\
1 \\
1\end{array}$ & $\begin{array}{r}32 \\
\geqslant 256 \\
\geqslant 256\end{array}$ \\
\hline $\begin{array}{l}\text { E. cloacae } 67 \text { (no plasmid) } \\
67 \text { (pLA2917) } \\
67 \text { (pN.JR3-2) }\end{array}$ & $\begin{array}{l}\geqslant 256 \\
\quad \ldots \\
\quad \ldots\end{array}$ & $\begin{array}{r}0.25 \\
0.25 \\
\leqslant 0.01\end{array}$ & $\begin{array}{l}2 \\
2 \\
0.06\end{array}$ & $\begin{array}{r}2 \\
256 \\
256\end{array}$ \\
\hline $\begin{array}{l}\text { E. cloacae } 68 \text { (no plasmid) } \\
68 \text { (pLA2917) } \\
68 \text { (pNJR3-2) }\end{array}$ & $\begin{array}{l}\geqslant \\
\quad 256 \\
\quad \cdots \\
\quad \cdots\end{array}$ & $\begin{array}{r}0.25 \\
0.25 \\
\leqslant 0.01\end{array}$ & $\begin{array}{l}2 \\
2 \\
0.06\end{array}$ & $\begin{array}{r}2 \\
256 \\
256\end{array}$ \\
\hline $\begin{array}{l}\text { E. cloacae } 89 \text { (no plasmid) } \\
89 \text { (pLA2917) } \\
89 \text { (pNJR3-2) }\end{array}$ & $\begin{array}{l}\geqslant 256 \\
\quad \cdots \\
\quad \cdots\end{array}$ & $\begin{array}{l}4 \\
4 \\
0.25\end{array}$ & $\begin{array}{r}16 \\
16 \\
1\end{array}$ & $\begin{array}{r}16 \\
\geqslant 256 \\
\geqslant 256\end{array}$ \\
\hline $\begin{array}{l}\text { E. cloacae } 105 \text { (no plasmid) } \\
105 \text { (pLA2917) } \\
105 \text { (pNJR3-2) }\end{array}$ & $\begin{array}{l}\geqslant 256 \\
\cdots \\
\cdots\end{array}$ & $\begin{array}{l}1 \\
1 \\
1\end{array}$ & $\begin{array}{l}4 \\
4 \\
4\end{array}$ & $\begin{array}{r}32 \\
\geqslant 256 \\
\geqslant 256\end{array}$ \\
\hline $\begin{array}{l}\text { E. cloacae } 110 \text { (no plasmid) } \\
110 \text { (pLA2917) } \\
110 \text { (pNJR3-2) }\end{array}$ & $\begin{array}{l}\geqslant 256 \\
\quad \ldots \\
\cdots\end{array}$ & $\begin{array}{r}0.25 \\
0.25 \\
\leqslant 0.01\end{array}$ & $\begin{array}{l}1 \\
1 \\
0.06\end{array}$ & $\begin{array}{r}2 \\
256 \\
256\end{array}$ \\
\hline $\begin{array}{l}\text { E. cloacae } 132 \text { (no plasmid) } \\
132 \text { (pLA2917) } \\
132 \text { (pNJR3-2) }\end{array}$ & $\begin{array}{l}\geqslant 256 \\
\ldots \\
\ldots\end{array}$ & $\begin{array}{l}1 \\
1 \\
0.06\end{array}$ & $\begin{array}{l}4 \\
4 \\
0.25\end{array}$ & $\begin{array}{r}16 \\
\geqslant 256 \\
\geqslant 256\end{array}$ \\
\hline
\end{tabular}

a

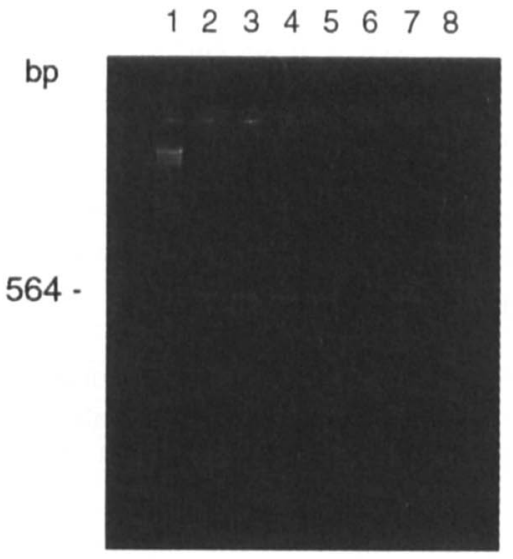

b $\begin{array}{lllllllll}1 & 2 & 3 & 4 & 5 & 6 & 7 & 8\end{array}$

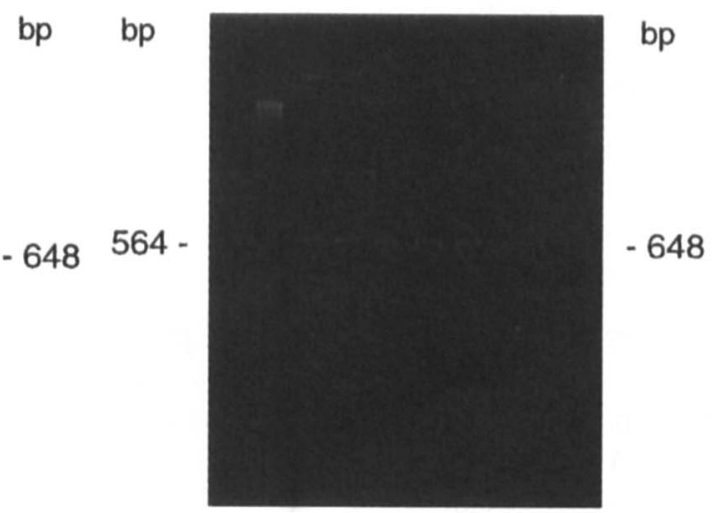

Fig. 1. Agarose gel electrophoresis of PCR products of gyrA from: (a) E. cloacae strains sensitive to or with low-level resistance to quinolones: lane 1, DNA marker $\lambda$ DNA-Hind III digest; 2-7, 648-bp amplification products of $E$. cloacae isolates $5,15,32,105,136$ and NCTC 10005, respectively; 8, negative control (-); (b) E. cloacae strains with resistance to quinolones: 1, DNA marker $\lambda$ DNA-Hind III digest; 2-7, 648-bp amplification products of $E$. cloacae isolates $19,67,68,89,110$ and 132 , respectively; 8, negative control (-). 
Table 2. Nucleotide sequence and amino-acid composition of QRDR of gyrA from the quinolone-sensitive E. cloacae strain NCTC 10005 and the most quinolone-resistant isolate E. cloacae no. 89

\begin{tabular}{lcccccccccc}
\hline NCTC 1005 & GGT & GAT & TCC & GCG & GTG & TAC & GAC & ACC & ATC & GTT \\
\hline \multirow{2}{*}{ Amino acid } & Gly & Asp & Ser & Ala & Val & Tyr & Asp & Thr & Ileu & Val \\
no. 89 & 81 & & 83 & & 85 & & 87 & & 89 & \\
& GGT & GAT & TAC & GCG & GTG & TAC & GAC & ACC & ATT & GTC \\
Amino acid & Gly & Asp & Tyr & Ala & Val & Tyr & Asp & Thr & Ileu & Val \\
\hline
\end{tabular}

Amino acid changes and point mutations are marked with bold letters. Hinfl restriction site is underlined.

a

$$
\begin{array}{llllllll}
1 & 2 & 3 & 4 & 5 & 6 & 7 & 8
\end{array}
$$

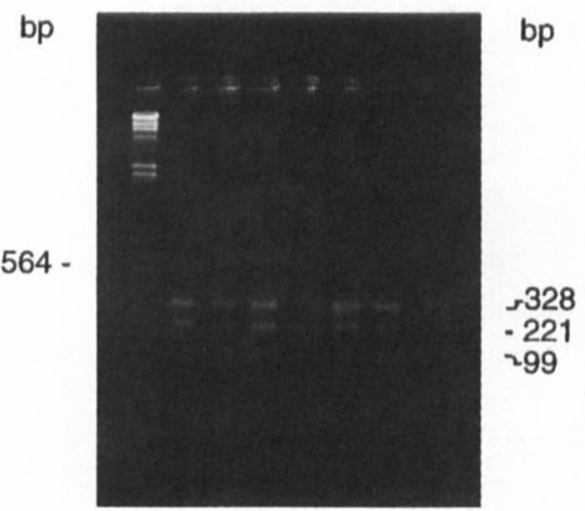

b
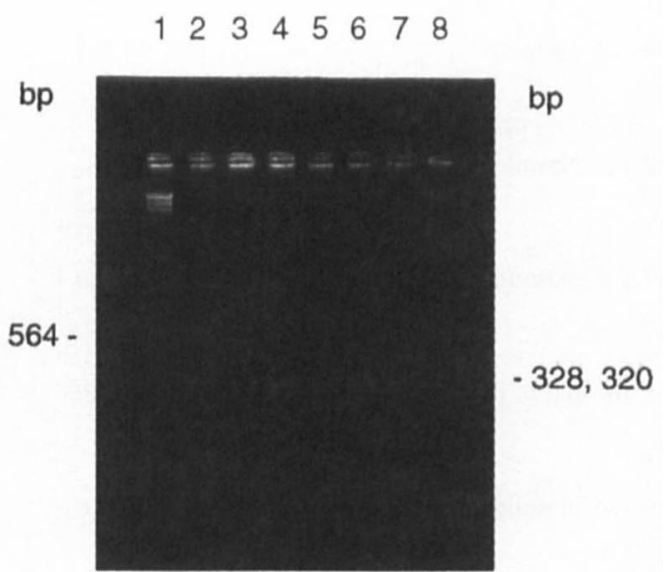

Fig. 2. Agarose gel electrophoresis of Hinf I digests of gyrA amplification products from: (a) quinolone-sensitive $E$. cloacae clinical isolates and those with low level resistance: lane 1, DNA marker $\lambda$ DNA-Hind III digest; 2-7, digests from isolates 5, 15, 32, 105, 136 and NCTC 10005, respectively; 8, negative control (-); (b) digests from quinoloneresistant $E$. cloacae isolates: 1, DNA marker $\lambda$ DNA-Hind III digest; 2-7, digests from isolates 19, 67, 68, 89, 110 and 132, respectively; 8 , negative control (-).

DNA fragments with sizes of 99,221 and $328 \mathrm{bp}$. This was seen with DNA from isolates 5, 15, 32, 105, 136 and E. cloacae NCTC 10005 (Fig. 2, panel a). However, mutation at the sequence corresponding to amino acid position 83 - as found in isolate 89 removes one HinfI site, so that digestion generated only two fragments, with sizes of 320 and 328 bp (Fig. 2 , panel b). All the clinical isolates $(19,67,68,89$, $110,132)$ for which the MICs of ofloxacin were $\geqslant 1 \mathrm{mg} / \mathrm{L}$, and that gave reversion of resistance in the dominance test, showed these two-band patterns after Hinf I digestion and electrophoresis.

\section{Discussion}

Quinolone resistance is often associated with point mutations in gyrA. This can be tested by a complementation method in which plasmids encoding quinolone-sensitive GyrA are transferred into resistant isolates. Sensitive gyrA is dominant to resistant so, if the original resistance is caused by mutation to $g y r A$, it is lost [7]. This method detects all mutations to gyrA, but gives no data on their nature. To address this aspect, gyrA genes from the most quinolone-resistant isolate (no. 89) and the control E. cloacae NCTC
10005 were amplified by PCR, and sequenced [20]. Analysis showed that gyrA from the resistant isolate had a mutation leading to replacement of serine 83 by tyrosine, together with silent mutations in the codons determining amino acids 89 and 90 . Mutation at serine 83 has also been reported as the first mutation step in quinolone resistance in Esch. coli [2]. Hinf I digestion of PCR-amplified DNA implied mutation at serine 83 in the gyrA genes of six further isolates with ofloxacin MICs $\geqslant 1 \mathrm{mg} / \mathrm{L}$. PCR-RFLP was a useful method to detect gyrA mutants at amino position 83 , serine, and, in contrast to the dominance tests, was simple and rapid [21]. This method could provide a rapid primary characterization of highly fluoroquinolone-resistant isolates.

Quinolone resistance can be associated with reduced impermeability of the outer membrane, active efflux, and mutations in $\operatorname{gyr} B[14,21,23,24]$. Four strains in this study retained diminished susceptibility after conjugation, implying the presence of one of these mechanisms, rather than gyrA mutation.

We are grateful to Laura Piddock (Department of Medical Microbiology, University of Birmingham) for Esch. coli S17-1 (pLA2917) and Esch. coli S17-1 (pNJR3-2). 


\section{References}

1. Falkiner FR. Enterobacter in hospital. J Hosp Infect 1992; 20: $137-140$.

2. Gaston MA. Enterobacter: an emerging nosocomial pathogen $J$ Hosp Infect 1988; 11: 197-208.

3. Ritter E, Thurm V, Bauernfeind A, Dorittke C, Völpel S, Finger H. Nosokomiale Kolonisation und Infektion durch multiresistente Enterobacter cloacae Stämme auf einer onkologischen Kinderstation. [Nosocomial colonization and infection by multiresistant Enterobacter cloacae strains on a pediatric oncology unit.] Zentralbl Hyg Umweltmed 1994; 196: 81-94.

4. Crumplin GC. Mechanisms of resistance to 4-quinolone antibacterial agents. J Antimicrob Chemother 1990; 26 Suppl F: $131-144$.

5. Piddock LJV. Mechanisms of resistance to quinolones and clinical perspectives. $J$ Antimicrob Chemother 1989; 23: $475-480$.

6. Lewin CS, Howard BMA, Smith JT. Protein- and RNA synthesis independent bactericidal activity of ciprofloxacin that involves the A subunit of DNA gyrase. J Med Microbiol 1991 34: 19-22.

7. Robbillard NJ. Broad-host-range gyrase A gene probe. Antimicrob Agents Chemother 1990; 34: 1889-1894.

8. Swanberg SL, Wang JC. Cloning and sequencing of the Escherichia coli gyrA gene coding for the A subunit of DNA gyrase. J Mol Biol 1987; 197: 729-736.

9. Oram M, Fisher LM. 4-Quinolone resistance mutations in the DNA gyrase of Escherichia coli clinical isolates identified by using the polymerase chain reaction. Antimicrob Agents Chemother 1991; 35: 387-389.

10. Vila J, Ruiz J, Goni P, Marcos A, Jimenez de Ante T. Mutation in the gyrA gene of quinolone-resistant clinical isolates of Acinetobacter baumannii. Antimicrob Agents Chemother 1995 39: 1201-1203.

11. Yonezawa $M$, Takahata $M$, Matsubara N, Watanabe $Y$, Narita H. DNA gyrase gyrA mutations in quinolone-resistant clinical isolates of Pseudomonas aeruginosa. Antimicrob Agents Chemother 1995; 39: 1970-1972.

12. Yoshida H, Bogaki M, Nakamura M, Nakamura S. Quinolone resistance-determining region in the DNA gyrase gyrA gene of Escherichia coli. Antimicrob Agents Chemother 1990; 34: $1271-1272$.

13. Power EGM, Muñoz-Bellido JL, Phillips I. Detection of ciprofloxacin resistance in Gram-negative bacteria due to alterations in gyrA. J Antimicrob Chemother 1992; 29: 9-17.

14. Lewin CS, Allen RA, Amyes SGB. Potential mechanisms of resistance to the modern fluorinated 4-quinolones. $J \mathrm{Med}$ Microbiol 1990; 31: 153-162.

15. Heisig P, Tschorny R. Characterization of fluoroquinoloneresistant mutants of Escherichia coli selected in vitro. Antimicrob Agents Chemother 1994; 38: 1284-1291.

16. Heisig $\mathrm{P}$, Schedletzky H, Falkenstein-Paul H. Mutations in the gyrA gene of a highly fluoroquinolone-resistant clinical isolate of Escherichia coli. Antimicrob Agents Chemother 1993; 37: 696-701.

17. Rahman M, Mauff G, Levy J et al. Detection of 4-quinolone resistance mutation in gyrA gene of Shigella dysenteriae type 1 by PCR. Antimicrob Agents Chemother 1994; 38: $2488-2491$

18. Sambrook J, Fritsch EF, Maniatis T. Molecular cloning: a laboratory manual, 2nd edn. Cold Spring Harbor, NY, Cold Spring Harbor Laboratory Press. 1989.

19. Middendorf LR, Bruce JC, Bruce RC et al. Continuous, on-line DNA sequencing using a versatile infrared laser scanner/ electrophoresis apparatus. Electrophoresis 1992; 13: 487-494.

20. Reece RJ, Maxwell A. DNA gyrase: structure and function Crit Rev Biochem Mol Biol 1991; 26: 335-375.

21. Dimri GP, Das HK. Cloning and sequence analysis of gyrA gene of Klebsiella pneumoniae. Nucleic Acids Res 1990; 18: $151-156$

22. Ishii $\mathrm{H}$, Sato $\mathrm{K}$, Hoshino $\mathrm{K}$ et al. Active efflux of ofloxacin by a highly quinolone-resistant strain of Proteus vulgaris. J Antimicrob Chemother 1991; 28: 827-836.

23. Bryan LE, Bedard J. Impermeability to quinolones in grampositive and gram-negative bacteria. Eur $J$ Clin Microbiol Infect Dis 1991; 10: 232-239.

24. Heisig P. High-level fluoroquinolone resistance in a Salmonella typhimurium isolate due to alterations in both gyrA and gyrB genes. J Antimicrob Chemother 1993; 32: 367-377. 